\title{
Knowledge sharing barriers in the Polish manufacturing companies
}

\author{
Justyna Patalas-Maliszewska \\ University of Zielona Góra \\ Poland \\ J.Patalas@iizp.uz.zgora.pl
}

Abstract. This study analyzes the knowledge sharing barriers in the manufacturing enter-

Received:

March, 2014

1st Revision:

April, 2014

Accepted:

May, 2014

culture in Poland is still at the initial stage, therefore it is significant to establish the use of the motivation tools in the context of knowledge culture development for Poland's enterprises. This study develops a framework of general knowledge sharing barriers reducing model from the individual, organizational and technology perspective, and further discusses the research results.

DOI:

Keywords: knowledge sharing barriers, knowledge culture, Polish manufacturing companies

JEL classification: M21, M29

\section{INTRODUCTION}

According to Vaccaro et al., (2010) knowledge sharing would facilitate a broad range of changes to the organization. Knowledge sharing activities in the companies are very important for preserving valuable heritage, learning new techniques, solving problems, creating core competences and initiating new situations (Hu et al., 2009), (Huang et al., 2010), (Law and Ngai, 2008), (Patalas-Maliszewska, 2013). Knowledge sharing was defined as an exchange involving the provision of personal experience and knowledge in return for economic and social benefits (Kankanhalli, Tan, and Wei, 2005).

Hofstede and Hofstede (2005) defined culture as the shared cognitive frames that guide the perceptions, thought, and language used by the members of a group and taught to new members in the early socialization process. Knowledge sharing among workers can be expressed in the form of human actions such as evaluations, attitudes, points of view, commitments and motivation (Koskinen, PihIanto, and Vanharanta, 2003), so in the knowledge culture.

According to McDermott and O’Dell (2001), De Long and Fahey, (2000) and King (2006) I state, that knowledge culture supports knowledge sharing. So the following questions may arise: whether knowledge culture characteristics influence knowledge sharing barriers reducing? What are the key knowledge sharing barriers that would be reduced? According to knowledge management literatures, this paper argues that knowledge culture practices have positive relationships with knowledge sharing barriers reducing directly and workers will see knowledge sharing as a natural activity in their daily business. 
This study aims to explore the relationships between knowledge culture and knowledge sharing barriers reducing. Based on a survey of 25 Polish manufacturing enterprises, this study employed the structural modeling to investigate the research hypothesis. The present study differs from previous works in three ways. Firstly, few studies have linked knowledge culture and knowledge sharing directly, this research attempts to fill this gap. Furthermore, this paper does not just testify the influence of knowledge culture on knowledge sharing, but also explores how this mechanism works through analyzing the mediating effect of the use of motivation tools in the context of knowledge culture. Finally, by discussing the influence of knowledge culture on knowledge sharing barriers reducing, this study proposes that when faced with different situation and requirements in the long term, managers should focus on specific knowledge culture characteristic and develop corresponding strategies within their organizations.

This paper is organized as follows. First review the literature on knowledge culture, knowledge sharing barriers is presented. Secondly, I develop my research model and articulate the corresponding hypotheses. The research methodology is then presented to clarify the construct operationalization and data collection procedure, followed by the section of data analysis results and hypotheses testing. Finally I provide research conclusions and implications.

\section{LITERATURE REVIEW, RESEARCH MODEL AND HYPOTHESES}

\subsection{Knowledge culture}

The extent to which a firm succeeds in sharing knowledge depends on the organizational culture (Austin, 1990); (Kim and Ju, 2008). Chiu and Hong (2006) defined, that there are many parts of a culture, including also a subjective culture, consisting of shared knowledge and ideas. I discuss the use of motivation tools in the enterprises in the context of knowledge culture. I suggest three knowledge culture characteristics (motivation tools) to reduce knowledge sharing barriers in the companies like as: workers evaluations, salary for new ideas /new research project / new product/service development, publicly/ individually praise.

\subsection{Knowledge sharing barriers}

Riege (2005) stated, that knowledge sharing barriers can be categorized to three levels: individual, organizational, and technology. As individual knowledge sharing barriers is generated mainly by lack of time resources for existing employees, language problems (Haldin-Herrgard, 2000), lack of trust (Hite, 2005), lack of social networks (Vermeulen and Barkema, 2001). During organizational knowledge sharing barriers, lack of proper space in which to share knowledge and lack or an exiguity of network connections (Riege, 2005), can become an issue (Gold, Malhotra and Segars, 2001). Furthermore as technology knowledge sharing barriers is generated mainly by lack of the necessary competence or willingness to employ technology (Riege, 2005), (Kłos and Patalas, 2013).

The paper aims to investigate the underlying influencing mechanism between knowledge culture and knowledge sharing barriers.

It was constructed a knowledge-based measure of firm's knowledge culture. The specific-item statement regarding knowledge culture in relation to each of the knowledge sharing barriers in use is: "Overall, the knowledge culture area of our firm reduces knowledge sharing barriers very well." The participants were asked either to agree or disagree with the item statement using a three-point Likert scale - ranging from: "disagree" (one point), "agree" (two points), "strongly agree" (three points). It was measured the following knowledge culture areas: workers evaluations, salary for new ideas /new research project/ new product/service development 
, publicly/ individually praise. The data for this study were collected from 25 Polish manufacturing companies (see Table 1) in which there is a significant existence of knowledge culture. The initial survey was tested by several experts. Based upon these tests, improvements were made in the wording and format.

Therefore, this study expects that the knowledge culture in Polish manufacturing companies will influence their knowledge sharing barriers reducing which, in turn, can lead to the following hypothesizes.

H1a. The use of workers evaluations as the part of knowledge culture in Polish manufacturing companies reduces individual knowledge sharing barriers.

H1b. The use of workers evaluations as the part of knowledge culture in Polish manufacturing companies reduces organisational knowledge sharing barriers.

H1c. The use of workers evaluations as the part of knowledge culture in Polish manufacturing companies reduces technology knowledge sharing barriers.

H2a. The use of salary for new ideas /new research project / new product/service development as the part of knowledge culture in Polish manufacturing companies reduces individual knowledge sharing barriers.

H2b. The use of salary for new ideas /new research project / new product/service development as the part of knowledge culture in Polish manufacturing companies reduces organizational knowledge sharing barriers.

$\mathrm{H} 2 \mathrm{c}$. The use of salary for new ideas /new research project / new product/service development as the part of knowledge culture in Polish manufacturing companies reduces technology knowledge sharing barriers.

$\mathrm{H} 3 \mathrm{a}$. The use of publicly/ individually praise as the part of knowledge culture in Polish manufacturing companies reduces individual knowledge sharing barriers.

$\mathrm{H} 3 \mathrm{~b}$. The use of publicly/ individually praise as the part of knowledge culture in Polish manufacturing companies reduces organizational knowledge sharing barriers.

$\mathrm{H} 3 \mathrm{c}$ : The use of $\mathrm{t}$ publicly/ individually praise as the part of knowledge culture in Polish manufacturing companies reduces technology knowledge sharing barriers.

Factors of knowledge sharing barriers in the manufacturing companies under study were based on feedback surveys and their sources are listed here: how satisfied are you with the knowledge sharing barriers reducing of your company with respect to...?

- using workers evaluations?

- using the salary for new ideas / new research project / new product/service development ,

- using publicly/ individually praise?

IKSB-factor1: I know that in my organization the knowledge culture is not very important for individual knowledge sharing barriers reducing of my firm.

IKSB-factor2: I know that in my organization the knowledge culture is quite important for individual knowledge sharing barriers reducing of my firm.

IKSB-factor3: I know that in my organization the knowledge culture is very important for individual knowledge sharing barriers reducing of my firm.

OKSB-factor 1: I know that in my organization the knowledge culture is not very important for organizational knowledge sharing barriers reducing of my firm.

OKSB-factor2: I know that in my organization the knowledge culture is quite important for organizational knowledge sharing barriers reducing of my firm.

OKSB-factor3: I know that in my organization the knowledge culture is very important for organizational knowledge sharing barriers reducing of my firm.

TKSB-factor1: I know that in my organization the knowledge culture is not very important for technology knowledge sharing barriers reducing of my firm. 
TKSB-factor2: I know that in my organization the knowledge culture is quite important for technology knowledge sharing barriers reducing of my firm.

TKSB-factor3: I know that in my organization the knowledge culture is very important for technology knowledge sharing barriers reducing of my firm.

The knowledge culture in the enterprise: The degree of the use of motivation tools by which one employee can collaborate with the knowledge and skills of another:

KC- WE1: It is used workers evaluations in my organization infrequently.

KC- WE2: It is used workers evaluations in my organization frequently.

KC- WE3: It is used workers evaluations in my organization very frequently.

KC-SN1: It is used the salary for new ideas /new research project / new product/service development in my organization infrequently.

KC-SN2: It is used the salary for new ideas/new research project / new product/service development in my organization frequently.

KC-SN3: It is used the salary for new ideas /new research project / new product/service development in my organization very frequently.

KC- P1: It is used using publicly/ individually praise in my organization infrequently.

$\mathrm{KC}-\mathrm{P} 2$ : It is used using publicly/ individually praise in my organization frequently.

$\mathrm{KC}$ - P3: It is used using publicly/ individually praise in my organization very frequently.

A research model in which the characteristics of knowledge culture are proposed to influence knowledge sharing barriers reducing directly is brought forward, as shown in Fig 1:

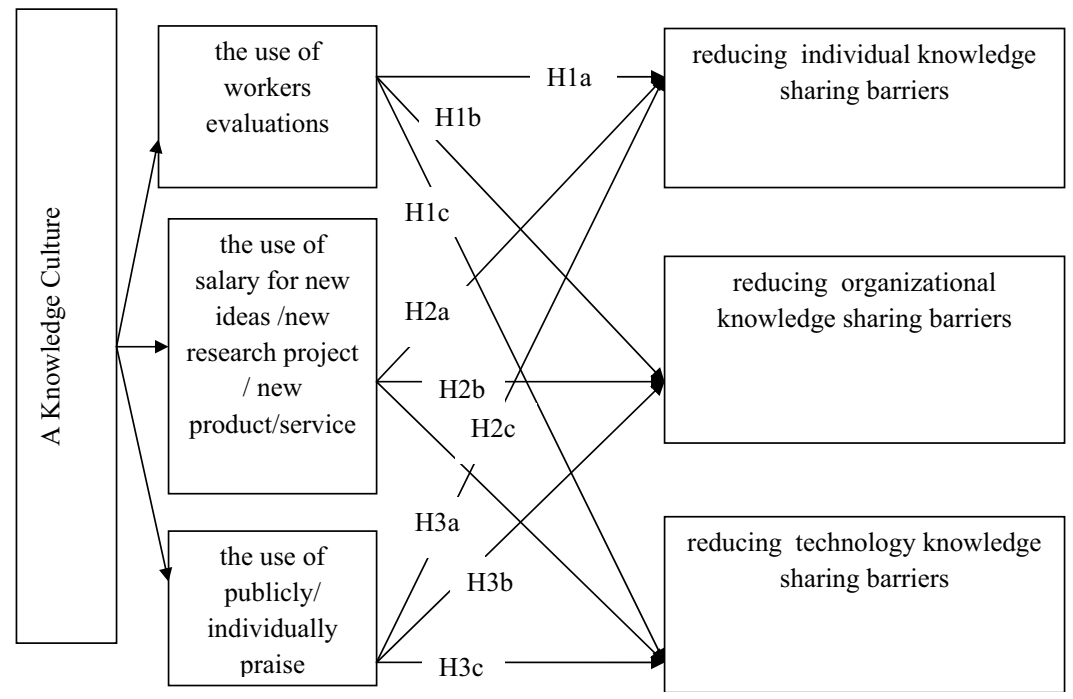

Fig. 1. Research model

The following section describes the item measurement and data collection carried out in my research. 


\section{MEASURES AND METHODS}

The objective of this study was to investigate how the use of motivation tools in the context of knowledge culture can influence knowledge sharing barriers reducing in Polish manufacturing companies. The survey used for testing the research model was developed by defining scales to fit the context of various knowledge variables. A three-point scale was used for all survey items, ranging from: "disagree" (one point), "agree" (two points), "strongly agree" (three points). The data for this study were collected from 25 Polish manufacturing companies. The survey was conducted in April 2013 through the use of direct interviews with respondents.

\section{RESEARCH RESULTS AND THE STRUCTURAL MODEL}

The research model was analysed using a correlation approach in order to estimate the effect of the use of various motivation tools in Polish manufacturing companies. A moderated correlation approach using Statistica ver.10.0 was used to test the hypotheses. The data were carefully examined with respect to linearity, equality of variance and normality. No significant deviations were detected. Table 2 presents descriptive correlations for the main variables. The study tested the hypotheses using correlation analysis because an interaction effect exists only if the interaction term makes a significant contribution.

Table 1

Correlation Analysis

\begin{tabular}{|c|c|c|c|c|c|}
\hline Construct & Item/Factor & Correlation & r2 & $\mathrm{t}$ & $\mathrm{p}$ \\
\hline 1 & 2 & 3 & 4 & 5 & 6 \\
\hline $\begin{array}{l}\text { Workers evaluations } \\
\text { individual knowledge sharing barri- } \\
\text { ers reducing }\end{array}$ & $\begin{array}{l}\text { KC- WE1/ KC- WE2/ KC- } \\
\text { WE3 } \\
\text { IKSB-factor1/ IKSB-factor2/ } \\
\text { IKSB-factor3 }\end{array}$ & 0,338241 & 0,114407 & 1,723744 & 0,098173 \\
\hline $\begin{array}{l}\text { Workers evaluations } \\
\text { organizational knowledge sharing } \\
\text { barriers reducing }\end{array}$ & $\begin{array}{l}\text { KC- WE1/ KC- WE2/ KC- } \\
\text { WE3 } \\
\text { OKSB-factor1/ OKSB-factor2/ } \\
\text { OKSB-factor3 }\end{array}$ & $-0,004429$ & 0,000020 & $-0,021242$ & 0,983236 \\
\hline $\begin{array}{l}\text { Workers evaluations } \\
\text { technology knowledge sharing barri- } \\
\text { ers reducing }\end{array}$ & $\begin{array}{l}\text { KC- WE1/ KC- WE2/ KC- } \\
\text { WE3 } \\
\text { TKSB-factor1/ TKSB-factor2/ } \\
\text { TKSB-factor3 }\end{array}$ & 0,076092 & 0,005790 & 0,365984 & 0,717722 \\
\hline $\begin{array}{l}\text { Salary for new ideas /new research } \\
\text { project / new product/service } \\
\text { individual knowledge sharing barri- } \\
\text { ers reducing }\end{array}$ & $\begin{array}{l}\text { KC- SN1/ KC- SN2/ KC- SN3 } \\
\text { IKSB-factor1/ IKSB-factor2/ } \\
\text { IKSB-factor3 }\end{array}$ & 0,181902 & 0,033088 & 0,88717 & 0,384170 \\
\hline $\begin{array}{l}\text { Salary for new ideas /new research } \\
\text { project / new product/service } \\
\text { organizational knowledge sharing } \\
\text { barriers reducing }\end{array}$ & $\begin{array}{l}\text { KC- SN1/ KC- SN2/ KC- SN3 } \\
\text { OKSB-factor1/ OKSB-factor2/ } \\
\text { OKSB-factor3 }\end{array}$ & $-0,514496$ & 0,264706 & $-2,87750$ & 0,008504 \\
\hline $\begin{array}{l}\text { Salary for new ideas /new research } \\
\text { project / new product/service } \\
\text { technology knowledge sharing barri- } \\
\text { ers reducing }\end{array}$ & $\begin{array}{l}\text { KC- SN1/ KC- SN2/ KC- SN3 } \\
\text { TKSB-factor1/ TKSB-factor2/ } \\
\text { TKSB-factor3 }\end{array}$ & 0,173313 & 0,030038 & 0,84395 & 0,407388 \\
\hline
\end{tabular}




\begin{tabular}{|l|l|l|l|l|l|}
\hline \multicolumn{1}{|c|}{1} & \multicolumn{1}{|c|}{2} & \multicolumn{1}{|c|}{4} & 5 & 6 \\
\hline $\begin{array}{l}\text { Publicly/ individually praise } \\
\text { individual knowledge sharing barri- } \\
\text { ers reducing }\end{array}$ & $\begin{array}{l}\text { KC- P1/ KC- P2/ KC- P3 } \\
\text { IKSB-factor1/ IKSB-factor2/ } \\
\text { IKSB-factor3 }\end{array}$ & 0,181902 & 0,033088 & 0,887171 & 0,384170 \\
\hline $\begin{array}{l}\text { Publicly/ individually praise } \\
\text { organizational knowledge sharing } \\
\text { barriers reducing }\end{array}$ & $\begin{array}{l}\text { KC- P1/ KC- P2/ KC- P3 } \\
\text { OKSB-factor1/ OKSB-factor2/ } \\
\text { OKSB-factor3 }\end{array}$ & 0,736015 & 0,541718 & 5,214155 & 0,000027 \\
\hline $\begin{array}{l}\text { Publicly/ individually praise } \\
\text { technology knowledge sharing barri- } \\
\text { ers reducing }\end{array}$ & $\begin{array}{l}\text { KC- P1/ KC- P2/ KC- P3 } \\
\text { TKSB-factor1/ TKSB-factor2/ } \\
\text { TKSB-factor3 }\end{array}$ & 0,173313 & 0,030038 & 0,843954 & 0,407388 \\
\hline
\end{tabular}

Table 1 presents descriptive correlations for the main variables. This includes the results of the correlation analyses which estimate the effect of the use of motivation tools in Polish manufacturing companies in the context of knowledge culture as well as their interaction on knowledge sharing barriers.

Hypotheses $\mathrm{H} 1 \mathrm{a}-\mathrm{c}, \mathrm{H} 2 \mathrm{a}, \mathrm{H} 2 \mathrm{c}, \mathrm{H} 3 \mathrm{a}$ and $\mathrm{H} 3 \mathrm{c}$ and are not confirmed by the research because the correlation of the use of motivation tools in the context of knowledge culture and reducing both individual and technology knowledge sharing barriers is not significant.

Table 1 shows that firms that focus on the use of salary for new ideas /new research project / new product/service in the context of knowledge culture achieve more organizational knowledge sharing barriers (corr $=-0,514496)$. Therefore, Hypothesis H2b regarding the interaction between the use of motivation tools in the context of knowledge culture in Polish manufacturing companies and reducing organizational knowledge sharing barriers is not supported by the data.

The interaction of the use of publicly/ individually praise makes a significant contribution to reducing organizational knowledge sharing barriers (corr $=0,736015$ ). So, hypothese $\mathrm{H} 3 \mathrm{~b}$ is also confirmed.

Structural model results are shown in Fig. 2.

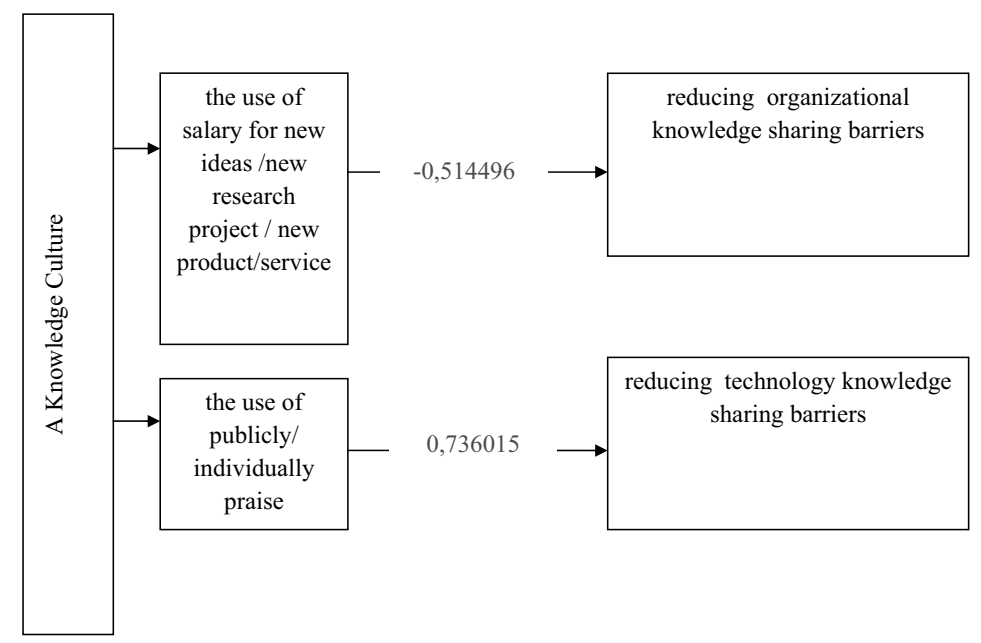

Fig. 2. Structural model 


\section{CONCLUSIONS AND RECOMMENDATIONS}

This section of the paper summarizes the new findings of this study and discusses the implications.

This research analyzes the effects of knowledge culture development in Polish manufacturing companies. It is based on using a comprehensive framework that integrates two research streams: the use of the motivation tools in the context of knowledge culture and knowledge sharing barriers.

The result of this study provides a set of important implications regarding knowledge sharing barriers using the motivation tools. $\mathrm{H} 3 \mathrm{~b}$ can be used as a general guiding principle for minimizing the organizational knowledge sharing barriers.

Using Proposition H3b, I can identify essential motivation tool which play a critical role in organsational knowledge sharing barriers reducing of the whole company. The findings of this paper will provide a set of useful guidelines for managing a company.

Like all studies, this one has certain limitations that further research should aim to overcome. Firstly, because the intention is to analyze knowledge sharing barriers, this study focuses on Polish manufacturing industries. It would be unwise to generalize the findings too broadly to other enterprises. Furthermore, all the variables are measured at the same moment in time. So, it would be useful to provide such research over a longer time period and at different stages. These conclusions and limitations suggest proposals for future research direction, such as exploring additional factors that could reduce the knowledge sharing barriers in a company.

\section{REFERENCES}

Austin, A.E. (1990), Faculty cultures, faculty values, New Directions for Institutional Research, Vol. 68, No. Winter, pp. 61-74.

Chiu, C.-Y., Hong, Y.-Y. (2006), Social Psychology of Culture, Psychology Press, New York.

De Long, D.W., Fahey, L. (2000), Diagnosing cultural barriers to knowledge management, Academy of Management Executive, Vol. 14, pp. 113-127.

Gold, A.H., Malhotra, A., Segars, A.H. (2001), Knowledge management: An organizational capabilities perspective, Journal of Management Information Systems, Vol. 11, No. 1, pp. 185-214.

Haldin-Herrgard, T. (2000), Difficulties in diffusion of tacit knowledge in organizations, Journal of Intellectual Capital, Vol. 1, No. 4, pp. 357-365.

Hite, J.M. (2005), Evolutionary processes and paths of relationally embedded network ties in emerging entrepreneurial firms, Entrepreneurship Theory \& Practice, Vol. 29, No. 1, pp. 113-143.

Hofstede, G., Hofstede, G.J. (2005), Cultures in organizations, Cultures Consequences, pp. 373-421.

Hu, M.L.M., Horng, J.S., Sun, Y.H.C. (2009), Hospitality teams: Knowledge sharing and service innovation performance, Tourism Management, Vol. 30, pp. 41-50.

Huang, Q., Davison, R.M., Gu J. (2010), The impact of trust, guanxi orientation and face on the intention of Chinese employees and managers to engage in peer-to-peer tacit and explicit knowledge sharing, Information Systems Journal, pp. 557-577

Kankanhalli, A., Tan, B., Wei, K.K. (2005), Contributing knowledge to electronic knowledge repositories: An empirical investigation, MIS Quarterly, Vol. 29, pp. 113-143.

Kim, S., Ju, B. (2008), An analysis of faculty perceptions: Attitudes towards knowledge sharing and collaboration in an academic institution, Library \& Information Science Research, Vol. 30, No. 4, pp. 282-290. 
King, W.R. (2006), Maybe a "knowledge culture" isn't so important after all! Information Systems Research, Vol. 2006, pp. 88-89.

Kłos, S, Patalas-Maliszewska, J (2013), The impact of ERP on maintenance management, Management and Production Engineering Review, Vol. 4, No. 3, pp. 15-25.

Koskinen, K.U., PihIanto, P., Vanharanta H. (2003), Tacit knowledge acquisition and sharing in a project work context, International Journal of Project Management, Kidlington, Vol. 21, No. 4, pp. 281-290.

Law, C.C.H., Ngai, E.W.T. (2008), An empirical study of the effects of knowledge sharing and learning behaviors on firm performance, Expert Systems with Applications, Vol. 34, pp. 2342-2349.

McDermott, R., O'Dell, C. (2001), Overcoming cultural barriers to sharing knowledge, Journal of Knowledge Management, Vol. 5, pp. 76-85.

Patalas-Maliszewska, J (2013), Knowledge Worker Management: Value Assessment, Methods, and Application Tools, Springer, Heidelberg Germany.

Riege, A. (2005), Three-dozen knowledge-sharing barriers managers must consider, Journal of Knowledge Management, Vol. 9, No. 3, pp. 18-35.

Vaccaro, A., Parente, R., Veloso, F.M. (2010), Knowledge management tools, inter-organizational relationships, innovation and firm performance, Technological Forecasting and Social Change, Vol. 77, pp. 1076-1089.

Vermeulen, F., Barkema, H. (2001), Learning through acquisitions, The Academy of Management Journal, Vol. 44, No.3, pp. 457-476. 